\title{
Exchange Rate Volatility and Import Trade Flow Evidence From India-U.S. at Industry Level
}

Mohini Gupta, Jaypee Institute of Information Technology, Noida, India

Sakshi Varshney, Jaypee Institute of Information Technology, Noida, India

\begin{abstract}
The interest of the study is to explore the impact of exchange rate volatility on the India-U.S. trade flow of import on six industries from September 2002 to June 2019. The authors investigate the relationship at disaggregate level by industry-wise data with monthly frequency. They employ exponential generalized autoregressive conditional heteroscedasticity (E-GARCH) model to gauge volatility and thereafter ARDL bound testing approach to unveil the short and long-run association of real exchange rate volatility and import. The empirical analysis implies the existence of both short-run and long-run effect in five importing industries except manufactured (engineering) goods. While real exchange volatility appears to have statistically significant effect in the short run, estimated short-run lasts onto long-run effect in only three industries. The results confirm the information of import in time-series analysis. The finding of the study helps to undertake the view of invariability and considering the industry before policy making.
\end{abstract}

\section{KEYWORDS}

ARDL, EGARCH, Exchange Rate Volatility, Import, India, Industry

\section{INTRODUCTION}

India's trade direction changed since 1991, the evident rise in the trade share with U.S. was seen. Historically India has been self- sufficient on the terms of trade earlier to 1990s, the strict government focused particularly on high tariff rates and bewildered on administrative restrictions and licenses. After 1991, government introduced trade policy regime including reduction in import tariffs, decanalisation and removal restrictions on import. There was radical change observed by reducing the tariff and non-tariff and introduction of exchange rate regime which further strengthened the India's trade energy. (Goldar, 2002; Topalova \& Khandelwal, 2011 and Mitra, Sharma, \& Ve, 2014). Also, India experienced growth in trade but due the crisis happened in U.S. has discouraged the growth of trade flow in India. Does exchange rate volatility discourage the bilateral trade of import between India and U.S.? To lay out this, this study is an attempt to analysing the impact of exchange rate volatility on import at disaggregates level which is industry level.

The reverberation of valuation on economic performance, international trade. There are commodious supporting literature on trade flow. The voluminous benefaction by Clark, (1973) and Peter Hooper, (1978) underline theory effectively. However, the analysis in this matter has always been not known authoritatively (Jerry G. Thursby, (1987) and Grauwe, (1988)) from their perspective of work, the evidence have negative relationship between exchange rate risk and import of the nation.

DOI: 10.4018/IJABIM.20210701.oa25

This article published as an Open Access article distributed under the terms of the Creative Commons Attribution License (http://creativecommons.org/licenses/by/4.0/) which permits unrestricted use, distribution, and production in any medium, provided the author of the original work and original publication source are properly credited. 
As observed over time, trade either its import or export elasticities, it remain unchanged and more of increasing elasticities and undertaking relative prices it further ameliorate the trade balance. Where, Williamson (1983), nonetheless mentioned that increase in prices of import more of due to the devaluation may lead to high price costing in the domestic goods. According to literature, the currency devaluation do effect the trade through different channels one of which is depreciation in real exchange rate. This create a positive turn out as competition in domestic market increases also improving the trade balances. It has develop an interest understanding to measure the effect of exchange rate on trade between two countries. Exchange rate volatility has always been inordinately sensitive variable; its extended deviations of currencies from their balanced level repeatedly press costs on the economy. Indian economy post liberalization has witnessed unexpectedly rise in import. Undertaking India's case the tariff levied on import has decreased from $87 \%$ to $45 \%$ during pre-liberalization to post liberalization era in 1987 to 1994 (Sharma \& Pal, 2019). The reverberation of exchange rate fluctuations on trade holds a large accumulation of studies. Nevertheless, many findings have measured on the trade across border of exchange rate volatility mainly focusing export and ignored the import. Unlike previous studies, this study offers supporting evidence of volatility of real exchange rate impacting import. Therefore, this paper offers first-hand evidence, to best of knowledge, in Indian context which explains the association of import at industry-level between India-U.S.

To this background, this study adds in the related existing literature and findings by casting econometric techniques to acquire robust and accurate results. As recognized that volatility of exchange rate cannot be applied in the model directly, by means of which there are various statistical techniques to measure volatility. Firstly, to estimate volatility from real exchange rate, a generalized autoregressive conditional heteroscedastic model $(\mathrm{GARCH})$ is utilized, as it is considered more appropriate and accurate than standard deviation based method. We apply EGARCH model to estimate volatility, it appeared to be the best relevant model. Further, moving forward, we use ARDL approach by M. Hashem Pesaran, Yongcheol Shin, (2001) to estimate the interlinkage of variation in real exchange rate and import trade industry-wise finding both short run and long run results. The ARDL modelling has accessory advantage on long run coefficients in accumulating reconcilable estimates which are asymptotically normal with the flexibility even when the underlying variables are of different order of integration. As the ARDL approach is favoured because of its exclusive assorted advantages in comparison to other co-integration procedures. In addition, it is not necessary a prior ascertainment of the order of the integration between the underlying variables, unalike other outlook of co-integration like Engle and Granger(1987), Johensen and Juselieus (1990) and Phillip and Hansen (1990) which necessitate same order of level of integration. Furthermore, ARDL approach also permits variables with different optimal lags. The overvaluation or undervaluation of exchange rate also make price movement in the import prices further scarcest the imports value (Emran \& Shilpi, 1996).Considering the impact of import at disintegrated level concern remain unsettled in findings. The most noticeable feature of Indian economy import substitution has been carefully taken into account because of its important role it raise development in India and ongoing plans. The industrial policies during prereform era were importantly designed to provide shield to domestic industries from competition of other nations (Sharma \& Mishra, 2015). Accordingly, second we use India-U.S. import trade, to which we disclose the linkage at industry level. The exploration of research is at micro level as to gain more specific and detailed information in reference to the relationship between exchange rate volatility and import trade flow at disaggregate level. Thirdly, we employ the association on monthly data rather than a quarterly or annual series, as the monthly series has high frequency to typically prime for variability measure. Finally, our results prediction consider real exchange rate over nominal exchange rate though there are many literature on this discussion explaining to which is more appropriate of both real and nominal exchange rate thereafter considering that our research is on bilateral trade which involves U.S. so we chose to use real exchange rate.

The aims of the research is to contribute to inquest the understanding of the association between volatility of real exchange rate and import at distributive level between India and U.S. bilaterally. 
First and foremost, this study probe the interlinkage between exchange rate fluctuation and India-U.S. import trading at Industry-wise consisting of time series outlook. To the best of our knowledge, this study explore industry trade of India with trading partner U.S. as there are voluminous literature only on aggregate analysis. As well known, India has followed the import substitution policy till 1991 and in foregoing years of 1991 India was a closed economy, but after trade liberalization in 1991, it checked great growth in import. Also India- U.S. has more trade of commodities under different industries comparatively to the other trading countries(Sharma \& Pal, 2018). Thereby, the United States is not chosen aimlessly as U.S. is first largest trading partner of India.

The rest of the paper is rubric as: next division entails the theoretical review in association of trade flow and exchange rate fluctuation. Section 3 delineates the measure of exchange rate volatility. Section 4 represents the data and methodology. Section 5 includes the empirical methodologies of the time series analysis of commodities. Section 6 delivers the conclusion and Section 7 covers the feasible policy implication. Sources and descriptive statistic is in Appendix A.

\section{THE LITERATURE OVERVIEW}

The interlinkage of volatility of real exchange rate and import trade flow is sensitive due to many factors. Due to, the lack of stability in currencies from the equ-balance point, it tends make changes in the behaviour of the pricing on the bilateral trade. The exchange rate can be undertaken as exogenous as well as endogenous from different frame of reference as like from the trader's currency variation view it is an exogenous factor where from the macro-economic or financial view it is an endogenous framework. We have distributed the related literature in two section delivering the relationship of exchange rate and trade balance, in next section explains relationship of exchange rate volatility with trade.

\subsection{Relationship Between Exchange Rate and Trade Balance}

As one of the extensive economic indicator, real exchange rate is simply the nominal exchange rate which takes inflation differential of home country and foreign country into account. (Rose, 1990) This study includes various developing countries to infer the effect of real exchange rate depreciation do improve the trade balance, which is also statistically supported by this study. According to Kharroubi, (2011) after globalisation, the relationship between real exchange and trade balance is affected as the growth gain in industries drives the trade balance to the real exchange rate more sensitive. (UK Essays November 2018) Marshall Lerner conditions suggests that depreciation of the exchange rate of one country's to other countries will boost the trade balance. Relationship between exchange rate and trade balance in Norway. Retrieved from A large and numerous studies has focused on the relationship between exchange rate and bilateral trade including countries Malaysia, Japan, China, US, New Zealand, Fiji and ten African countries (for instance Narayan, 2004; Baharumshah, 2001; Baharumshah and Yol, 2007; Kyereme, 2002) claims the significant relationship. Brahmasrene (2002), also holds that impact of real exchange rate and trade balance of Thailand with its trading partners predicts the significant relationship between real exchange rate and trade balance. In the systematic review, Ali, Johari, \& Alias, (2014) explains the four approaches namely standard theory of international trade, elasticity approach, Keysian absorption approach and monetary approach overview the effect of exchange rate movement on trade balance. Where, J-curve approach attracts more attention as it can testify both short-run and long-run coefficient of real exchange rate using econometric techniques and also it helps in tracing the effect between trade balance and exchange rate. (Singh, 2002) This study predict distinct effect of nominal and real exchange rate on trade, as the empirical evidence predicts the long-run elasticity with real exchange rate rather than nominal exchange rate. However, stating on to monitories the real exchange rate.

The definition of real exchange rate is distributed in two category: first category consist of purchasing power parity (PPP) and second is tradeable or non-tradeable goods. As the concentration 
of this paper is on tradable goods, also considering tradeable goods direct the competitiveness in the international market (Abbas Ali, Johari, \& Haji Alias, 2014). In the study of Tandon, (2014), the article exhibit the findings on panel of regions taking period of 1980-2010 on bilateral trade focusing on import. The finding of import supports the theory of exchange rate and the changes in exchange rate. Also, Rajković, Bjelić, Jaćimović, \& Verbič, (2020) predicts the association between foreign trade balance and real exchange rate undertaking Central and Eastern European (CEE) countries, and findings predict that in the economic crises scenario the nation which used their own currency experiences depreciating in the currency. Similarly there are more studies of different nation giving reflecting findings for instance, Arize, Malindretos, \& Igwe, (2017); Dogru, Isik, \& Sirakaya-Turk, (2019) and Choi, (2019).

\subsection{Relation Between Exchange Rate Volatility and Bilateral Trade}

In prior studies, Clark(1973) findings explores the influence variability of exchange rate on international trade flow by taking each individual product and the earning remain in foreign currency where revenue is captured because the native currency is considered keeping the watch of variability. The Clark's establishment excavate the negative and significant findings between the variability and trade across the different nations. Adding to the findings many articles provides support to the similar work till 1990 for example Baron, D.,1976; Peter Hooper, 1978; Cushman, 1988 and Giovannini, 1988. Uniformly, an empirical study by Arize, (1997) findings underpin significant and negative result of seven industrialized nations which are Denmark, the U.S., Germany, the U.K., Japan, Switzerland and Italy. As companies decide to distribute goods in different markets based on the fluctuation of exchange rate releases, Eckwert(1999) represents a positive relationship between foreign trade and exchange rate volatility. Opposing to previous mentioned studies, Maurice Obstfeld, (1998) gives a revelations on how the exchange rate fluctuation dampen the cross-border trade when all the risk-averse industries stands against it. Thus, the literature from the early beginning debate on the interlinkage between import and exchange rate movements or changes ending with distinct findings leaving inconclusive decisions.

On the empirical front, Bredin, Fountas, and Murphy(2003) describe how exchange rate volatility has a positive long-run effect but no short-run impact on Ireland's export and import to the European Union. Hondroyiannis, Swamy, Tavlas, and Ulan(2008) investigate the impact of exchange rate variance on both export and import for 11 industrialized economies (namely the United States, Canada, Italy, France, Germany, Japan, Switzerland, the United Kingdom, Ireland, the Netherlands, Norway, and Spain), and find no evidence of a direct link between volatility and export and import. Similar vein, Hall, Hondroyiannis, Swamy, Tavlas, \& Ulan,(2010) and Boug \& Fagereng,(2010) fail to explain that exchange rate volatility has a serious and negative effect on imports of the countries studied. Just from the other end, Myint Moe Chit(2010) investigated trade amongst 13 developing countries, including five emerging nations, and noticed that ambiguity or variability has a detrimental affect on cross-border trade. Whereas Bahmani-oskooee, Harvey, and Hegerty(2013) uncover bilateral trade between Brazil and the United States and provide minimal proof of long-term effects on most industries. Similarly, Asteriou et al., (2016) has not evidently find undeviating results of exchange rate variability with export and import. Equally, Asteriou et al.,(2016) did not notice any significant differences in the effects of exchange rate fluctuations on export and import.

Sharma and Pal (2018), as well as Bahmani oskooee, Harvey and Hegerty (2018), look for evidence of a substantial negative variability of returns on bilateral and inter trade. In Kang \& Dagli, (2018) findings the aftermath of the global financial crisis (GFC) and the emergence of global and regional value chains, this paper examines the relationship between international trade and exchange rate levels (GVCs). Likewise, many paper investigate the symmetric effects of exchange rate fluctuations on developing industrial trade flows (Arbabian, Ghasemy, \& Seyedghaleeh, 2019). In study of Jiménezrodríguez \& Morales-zumaquero, (2019) provides empirical support for the connection between exchange rate international element fluctuations and macroeconomic indicators. Correspondingly, 
the work on demand functions for total imports and their subcomponents are calculated separately, and the corresponding time varying elasticities are obtained using the Kalman filter process. The findings indicate that income and relative price changes account for the majority of total import growth (Çulha, Eren, \& Öğünç, 2019). Overall, the numerous studies representing various observations of the impact of exchange rate volatility on trade are largely ambiguous. As a result, a study of bilateral trade performance at a subtle level in developed countries is essential.

\section{MODEL REPRESENTATION OF EXCHANGE RATE VOLATILITY}

The literature on whether to use an actual or nominal exchange rate to quantify volatility when computing the interaction with trade flow is comprehensive. Many researchers (for example, Bahmanioskooee \& Hegerty,2007; Bahmani-oskooee \& Aftab,2017; Bahmani-oskooee \& Arize,2019) do use the real exchange rate for their analysis methods so the nominal exchange rate does not include the variance, although the real exchange rate does. To reduce the aggregation bias used on trade flow at the bilateral level, the calculation of volatility is centred on the real exchange rate. As a result, the real-term volatility of the India-US exchange rate is calculated. The monthly exchange rate data comes from the International Financial Statistics (IFS) and covers the years 2004:M12 to 2019:M03. Finally, using GARCH, the exchange rate volatility sequence for India and its trading partner, the United States, is statistically calculated.

The various academic studies include alternative approaches to calculate exchange rate volatility. For example, several papers (Ariccia,1999, Klaassen,2004, Devereux \& Lane,2003) adopted different statistical tests to investigate variability in the log exchange rate, such as standard deviation of the first difference or moving average standard deviation. On the other side many researchers used the general autoregressive conditional heteroskedasticity $(\mathrm{GARCH})$ modeling to measure exchange rate volatility. The GARCH-based model is the most successful because it reliably captures uncertainty with time-varying conditional variance.

The exchange rate volatility is further estimated by applying GARCH based model but prior to that the stationarity of exchange rate data series is essential to check. The augmented dickey-fuller (ADF) test of Dickey \& Fuller, (1979) is used for the stationarity check of real exchange rate, provided it is already in logarithm form. The test result is presented in the Table 2, which state that it is stationary at first difference and not at level.

Since it is impossible to reach directly, exchange rate volatility must be calculated. For estimating the volatility of the real exchange rate, we use a variety of GARCH-based models (see Table 3). We included GARCH $(1,1)$ based modelling to decide exchange rate volatility, which involves applying the GARCH model priory to the data. Next, to monitor volatility, we utilize asymmetric models such as Nelson's E-GARCH(1991) and Glosten, Jagannathan, \& Runkle's(1993) and Zakoian's (1994). Further to check the suitability among them we consider Akaike information criterion (AIC) and Bayesian information criterion (BIC) to choose most relevant technique. As a consequence, the criterion's result in Table 3 suggests that the E-GARCH model can be used to calculate volatility. Therefore, the result in Table 3 of the criterion suggest of E-GARCH model to measure volatility. That according USD-IND, the E-GARCH model is the best because it meets all of the requirements. The following is a summary of Nelson's E-GARCH from 1991.

$$
\log \left(h_{t}\right)=\omega+a\left[\frac{u_{t}-1}{\sqrt{h_{t}-a}}-\sqrt{2 / \pi} \|+\beta \log h_{t}-1+\gamma \frac{u_{t}-1}{\sqrt{h_{t}-1}}\right.
$$


Table 1 Summary of recent literature

\begin{tabular}{|c|c|c|c|c|}
\hline Authors & Period & Variables & Methods/Approach & Findings \\
\hline Kim, C. B. (2017) & $\begin{array}{l}2000 \text { to } \\
2015\end{array}$ & $\begin{array}{l}\text { Exchange rate } \\
\text { volatility and } \\
\text { Import }\end{array}$ & ARDL & $\begin{array}{l}\text { The USD/KRW exchange rate } \\
\text { volatility has a statistically significant } \\
\text { negative influence on Korea's } \\
\text { seaborne import volume., }\end{array}$ \\
\hline $\begin{array}{l}\text { Bernardin } \\
\text { Senadza and } \\
\text { DesmondDelali } \\
\text { Diaba (2017) }\end{array}$ & $\begin{array}{l}1993 \text { to } \\
2014\end{array}$ & $\begin{array}{l}\text { Exchange rate } \\
\text { volatility and } \\
\text { Import }\end{array}$ & PMG estimator & $\begin{array}{l}\text { There is no significant effects of } \\
\text { exchange rate volatility on imports. }\end{array}$ \\
\hline $\begin{array}{l}\text { Mohsen } \\
\text { Bahmani- } \\
\text { Oskooee, Abera } \\
\text { Gelan (2018) }\end{array}$ & $\begin{array}{l}\text { 1971Q1- } \\
\text { 2015Q4 }\end{array}$ & $\begin{array}{l}\text { Real exchange } \\
\text { rate volatility and } \\
\text { Trade }\end{array}$ & ARDL & $\begin{array}{l}\text { Exchange rate volatility affects trade } \\
\text { flows in the short run, the long-run } \\
\text { effects on the imports of only one of } \\
\text { twelve country. }\end{array}$ \\
\hline $\begin{array}{l}\text { Muhia John } \\
\text { Gachunga (2018) }\end{array}$ & $1980-2015$ & $\begin{array}{l}\text { Real exchange } \\
\text { rate volatility, } \\
\text { Import and } \\
\text { Export }\end{array}$ & $\begin{array}{l}\text { Log-linear multiple } \\
\text { regression }\end{array}$ & $\begin{array}{l}\text { The results show that the volatility of } \\
\text { the real exchange rate significantly } \\
\text { affects imports and exports. }\end{array}$ \\
\hline $\begin{array}{l}\text { Yifan Li and } \\
\text { Zhuang Miao } \\
(2019)\end{array}$ & $2000-2017$ & $\begin{array}{l}\text { Exchange rate } \\
\text { volatility and } \\
\text { Import }\end{array}$ & Panel regression & $\begin{array}{l}\text { The exchange rate volatility confirms } \\
\text { a financial constraints at firm level. }\end{array}$ \\
\hline $\begin{array}{l}\text { Vinh Nguyen Thi } \\
\text { Thuy and Duong } \\
\text { Trinh Thi Thuy } \\
\text { (2019) }\end{array}$ & $\begin{array}{l}\text { 2000Q1- } \\
2014 Q 4\end{array}$ & $\begin{array}{l}\text { Export, foreign } \\
\text { income and } \\
\text { exchange rate } \\
\text { volatility }\end{array}$ & ARDL & $\begin{array}{l}\text { The results show that exchange } \\
\text { rate volatility negatively affects } \\
\text { the export volume in the long run. }\end{array}$ \\
\hline $\begin{array}{l}\text { Fatbardha } \\
\text { Morina, } \\
\text { Eglantina Hysa, } \\
\text { Marian Catalin } \\
\text { Voica, U־gur } \\
\text { Ergün, Mirela } \\
\text { Panai (2020) }\end{array}$ & 2002-2018 & $\begin{array}{l}\text { Real exchange } \\
\text { rate volatility and } \\
\text { Economic growth }\end{array}$ & FMOLS & $\begin{array}{l}\text { The empirical findings using the } \\
\text { fixed effects estimation for panel } \\
\text { data reveal that the volatility of the } \\
\text { exchange rate has a significant negative } \\
\text { effect on real economic growth. }\end{array}$ \\
\hline $\begin{array}{l}\text { Blavasciunaite, } \\
\text { Deimante, } \\
\text { Garsviene, Lina } \\
\text { Matuzeviciute, } \\
\text { Kristina (2020) }\end{array}$ & $1998-2018$ & $\begin{array}{l}\text { Trade Balance } \\
\text { and Economic } \\
\text { growth }\end{array}$ & $\begin{array}{l}\text { OLS method } \\
\text { of multivariate } \\
\text { regression analysis }\end{array}$ & $\begin{array}{l}\text { Trade balance periods, results indicate } \\
\text { the negative and lagging impact of the } \\
\text { trade balance on economic growth. }\end{array}$ \\
\hline $\begin{array}{l}\text { Lilik Sugiharti, } \\
\text { Miguel Angel } \\
\text { Esquivias and } \\
\text { Bekti Setyorani } \\
\text { Departement } \\
(2020)\end{array}$ & $\begin{array}{l}2006 \text { to } \\
2018\end{array}$ & $\begin{array}{l}\text { Exchange rate } \\
\text { volatility and } \\
\text { Export }\end{array}$ & ARDL & $\begin{array}{l}\text { The exchange rate volatility has a } \\
\text { significant effect ores, chemicals, } \\
\text { rubber, pulp paper either in the short } \\
\text { or long-run. }\end{array}$ \\
\hline
\end{tabular}

Notes: Autoregressive Distributed Lag (ARDL); Pooled Mean-Group (PMG); Fully Modified Ordinary Least Square (FMOLS) and Ordinary Least Square (OLS).

Source: Authors Compilation

\section{DATA AND MODEL SPECIFICATION}

\subsection{Time Series Data of Industries}

To re-explore the effect of currency movements on India's imports from its trading partner, the United States. The United States was chosen over other trading countries because the amount of industries imported from the United States is higher than in other countries. The data of import is sourced 
Table 2 Unit root Test

\begin{tabular}{|l|l|l|l|}
\hline \multicolumn{5}{|c|}{ ADF results } \\
\hline \multicolumn{3}{|c|}{ At Level } \\
\hline Exchange rate & Intercept & Intercept \& Trend & None \\
\hline & 0.1773 & -2.3629 & 2.3117 \\
\hline \multicolumn{5}{|l|}{ At First Difference } & None \\
\hline Exchange rate & Intercept & Intercept \& Trend & $-8.9270^{* * *}$ \\
\hline & $-9.3099 * * *$ & $-9.3552^{* * *}$ & \\
\hline
\end{tabular}

Notes: 1. exchange rate is in natural logarithm form, $2 .{ }^{* *}$ denotes $5 \%$ level of significance; ${ }^{* *}$ denotes $1 \%$ level of significance.

from "Economic Outlook" a dataset of Centre for Monitoring Indian Economy (CMIE) ${ }^{1}$. We take 6 industries for the trade series of imports from India to the United States, covering the time frame from 2002:M09 to 2019:M06, related to data availability respectively. In the demand function from the same database, the industries are measured in volume. The study's variables are all translated into logarithmic form. Majorly the studies in the similar interest has used gross domestic product (GDP) as a measure of national income. But, our study use monthly data series and GDP is only available in either quarterly or annual manner. Thus, aggregate industrial production index (IIP) is used as proxy for national income (GDP) for the analysis. Furthermore, due to the Great Depression in the year2008, we have included dummy variables, dummy'08, in every model to capture the impact of such a dramatic year.

\subsection{Model Specification}

The study includes data on bilateral trade as well as data on industry trade as stated by India. The article concentrates on capturing the impact of uncertainty in both the long and short term. As the dataset is a combination of both stationary $\mathrm{I}(0)$ and non stationary variables $\mathrm{I}(1)$. We then use autogressive distributed lag method (ARDL) of M. Hashem Pesaran, Yongcheol Shin, (2001), that are used in the majority of literature. The paper presents the import trade flow from

the India's perspective. Majority of literature like Jerry G. Thursby, (1987); Peel, (1991); Varangis, (1994); Bahmani-Oskooee, M., \& Hegerty, S. (2009) confirms that import depends on other country's income. Therefore, the log-linear long-run import function is defined as follows:

$$
\ln M_{t}^{I N D}=\alpha+b \ln Y_{t}^{I N D}+c \ln R E R_{t}+d \ln V O L_{t}+\epsilon_{t}
$$

In Eq. (2) Where lnM, InY, RER, VOL denote India's import volume, India's income proxied by industrial output, exchange rate, exchange rate volatility as calculated in the preceding section, import

Table 3 Model selection criterion

\begin{tabular}{|l|l|l|l|}
\hline Exchange rate & \multicolumn{1}{|c|}{ Models } & \multicolumn{1}{|c|}{ AIC } & \multicolumn{1}{c|}{ BIC } \\
\hline & GARCH $(1,1)$ & 4.265710 & 4.363976 \\
\hline & T-GARCH $(1,1)$ & 4.226217 & 4.340860 \\
\hline & E-GARCH $(1,1)^{*}$ & 4.187662 & 4.302305 \\
\hline
\end{tabular}

Notes: 1. * denotes specific volatility estimation model, 2. AIC: Akaike information criterion, BIC: Bayesian information criterion. 
volume of the industries at time $t$, and $l n$ denotes the variables in logarithm terms respectively. The India's import is expected to depend positively with the India's own income and also with the RER which means $b$ could be positive and $c$ could be positive. The VOL is the exchange rate uncertainty, its effect could either be positive or negative, impression of $d$ could be negative or positive.

Eq. (2) estimates the longrun effects of U.S. income, exchange rate volatility, and real exchange on the import volume of each industry, as stated in several previous studies. The research did, however, look at the short-term consequences of exchange rate fluctuations. Thereafter, following the application of approach by Bahmani-oskooee \& Tankui, (2008) we reframe the Eq. (2) in error correction model as follows:

$$
\begin{aligned}
& \Delta \ln M_{t}^{I N D}=c_{1}+\sum_{j=1}^{n 1} y_{j} \Delta \ln M^{I N D} t-j+\sum_{j=0}^{n 2} \delta_{j} \Delta \ln Y_{t-j}^{I N D}+\sum_{j=0}^{n 3} k_{j} \Delta \ln R E R_{t-j} \\
& \sum_{j=0}^{n 4} \lambda_{j} \Delta \ln V O L_{t-j}+\alpha_{1} \ln M_{t-1}^{I N D}+\alpha_{2} \ln Y_{t-1}^{I N D}+\alpha_{3} \ln R E R_{t-1}+\alpha_{4} \ln V O L_{t-1}+\varepsilon_{t}
\end{aligned}
$$

Eq. (3) represents the error correction model, Pesaran et al.(2001) by using the F statistic test, explain how to use the OLS technique to capture non-stationary (I1) and stationary (I0) variables in the error correction model. If the F-test is jointly relevant, the variables are cointegrated, and the lagged variables are retained in Eq (3). The bound-test approach by Pesaran et al.(2001) keeps the assumption of $\mathrm{I}(1)$ as upper bound and $\mathrm{I}(0)$ as lower bound for the use of critical values. When the F-statistic is above the critical value of the upper estimate, the guarantee of a long-run relationship between two variables is recorded, but when it is underneath the critical value of the lower bound, there is no co-integration between variables. The assessment of $\lambda_{j}$ and $\alpha_{1}-\alpha_{4}$ in the estimation of Eq.(3), after normalisation of $\alpha_{1}{ }^{2}$, determines the short-run and long-run effect of exchange rate volatility. As described before, (Bahmani-oskooee \& Mitra, 2008) the model (3) holds the assumption of being symmetric.

\section{EMPIRICAL RESULTS}

As explained earlier, the body of research have concentrated on the impact of annual results, but in this review, we are using monthly series of industries from 2002:M09 to 2019:M06 for all analytical estimation models. The India demand model is again determined using an error-correction model (Eq. 3 ) on the aggregate of India imports to the United States, that is seen under the name of all industries. Similarly, we extend the error-correction model to each of the six Indian importing industries to see how they reveal the impact of exchange rate fluctuations.. Since we're working with monthly results, we're use the threshold of eight lags on each first-differenced element, and perhaps even the Akaike Information Criterion (AIC) to find the best model. We use *** as a 1 percent significance level, ** as a 5 percent significance level, and $*$ as a 10 percent significance level for diagnostic statistics and forecasts. For the concision of presentation, only coefficient estimates of short-run exchange rate volatility and coefficient estimates of long-run of all the variables are reported in Table 4, where its diagnostic statistics description is in Table 5 respectively.

Now, out using linear import demand model(1), India's aggregate imports (all industries) to the United States are important, indicating both the short- and long-run effects of exchange rate fluctuations in the coefficient estimates. . We relate the results at the industry level of 6 importing sectors from India to the United States to prevent prejudice against aggregation. The consequence of short-run forecasts from six industries (except engineering products manufacturing) with at least one meaningful coefficient (at the 10\% significance level), resulting in the impact of exchange rate fluctuations on import industries in the short run. Conversely, the result of the short-run on the long-run is only recorded in two industries in Table 4 . And it seems from the results, aggregate imports include a significantly negative estimated 
Table 4 Short run \& Long run coefficient of import model using ARDL

\begin{tabular}{|c|c|c|c|c|c|c|c|c|c|}
\hline \multirow[b]{2}{*}{ INDUSTRIES } & \multicolumn{4}{|c|}{ Short-run coefficient estimates } & \multicolumn{5}{|c|}{ Long-run coefficient estimates } \\
\hline & $\Delta$ LnVOLt & $\Delta$ LnVOLt-1 & $\Delta$ LnVOLt-2 & $\Delta$ LnVOLt-3 & Constant & LnPrice & LnYIND & LnRER & LnVOL \\
\hline Import & $\begin{array}{l}-0.04 \\
(2.06)^{* *}\end{array}$ & & & & $\begin{array}{l}4.55 \\
(9.60)^{* * * *}\end{array}$ & $\begin{array}{l}-0.30 \\
(1.36)\end{array}$ & $\begin{array}{l}1.65 \\
(4.03)^{* * * *}\end{array}$ & $\begin{array}{l}-0.22 \\
(1.15)\end{array}$ & $-0.03(2.06)^{* *}$ \\
\hline $\begin{array}{l}\text { Agricultural } \\
\text { and allied } \\
\text { products }\end{array}$ & $\begin{array}{l}-0.02 \\
(0.56)\end{array}$ & $-0.03(0.96)$ & $\begin{array}{l}0.08 \\
(2.75)^{* * *} *\end{array}$ & $-0.05(1.81)^{*}$ & $\begin{array}{l}0.07 \\
(0.08)\end{array}$ & $\begin{array}{l}-0.55 \\
(1.29)\end{array}$ & $\begin{array}{l}1.35 \\
(1.70)^{*}\end{array}$ & $\begin{array}{l}0.71 \\
(1.89)^{*}\end{array}$ & $-0.05(2.02)^{* * *}$ \\
\hline $\begin{array}{l}\text { Ores and } \\
\text { minerals }\end{array}$ & $\begin{array}{l}-0.02 \\
(0.67)\end{array}$ & $0.03(0.84)$ & $\begin{array}{l}-0.09 \\
(2.63)^{* * * *}\end{array}$ & & $\begin{array}{l}-0.03 \\
(0.01)\end{array}$ & $\begin{array}{l}-0.24 \\
(0.23)\end{array}$ & $3.29(1.68)$ & $\begin{array}{l}-1.66 \\
(1.75)^{*}\end{array}$ & $0.85(1.26)$ \\
\hline $\begin{array}{l}\text { Manufactured } \\
\text { goods } \\
\text { (Chemicals } \\
\text { and related } \\
\text { products) }\end{array}$ & $\begin{array}{l}0.02 \\
(1.73)^{*}\end{array}$ & $\begin{array}{l}-0.03 \\
(1.97)^{* *}\end{array}$ & & & $\begin{array}{l}5.01 \\
(13.98)^{* * * *}\end{array}$ & $\begin{array}{l}-0.52 \\
(4.25)^{* * *}\end{array}$ & $\begin{array}{l}1.61 \\
(6.40)^{* * * *}\end{array}$ & $\begin{array}{l}-0.12 \\
(0.96)\end{array}$ & $0.20(3.33)^{* * * *}$ \\
\hline $\begin{array}{l}\text { Manufactured } \\
\text { goods } \\
\text { (Engineering } \\
\text { goods) }\end{array}$ & $\begin{array}{l}0.01 \\
(0.77)\end{array}$ & & & & $\begin{array}{l}4.21 \\
(9.16)^{* * * *}\end{array}$ & $\begin{array}{l}-0.92 \\
(4.04)^{* * * *}\end{array}$ & $\begin{array}{l}2.23 \\
(5.39)^{* * * *}\end{array}$ & $\begin{array}{l}-0.44 \\
(2.30)^{* * * *}\end{array}$ & $0.01(0.94)$ \\
\hline Textiles & $\begin{array}{l}-0.07 \\
(2.56)^{* * * *}\end{array}$ & & & & $\begin{array}{l}2.65 \\
(4.50)^{* * * *}\end{array}$ & $\begin{array}{l}-1.44 \\
(5.94)^{* * * *}\end{array}$ & $\begin{array}{l}2.07 \\
(4.29)^{* * * *}\end{array}$ & $\begin{array}{l}-0.26 \\
(1.09)\end{array}$ & $0.01(0.50)$ \\
\hline $\begin{array}{l}\text { Other } \\
\text { manufactured } \\
\text { goods }\end{array}$ & $\begin{array}{l}0.34 \\
(2.04)^{* * *}\end{array}$ & & & & $\begin{array}{l}-1.76 \\
(1.39)\end{array}$ & $\begin{array}{l}-0.10 \\
(0.18)\end{array}$ & $\begin{array}{l}2.31 \\
(2.20)^{* * *}\end{array}$ & $\begin{array}{l}-0.01 \\
(0.02)\end{array}$ & $-0.05(1.67)$ \\
\hline
\end{tabular}

Notes: (a) Number inside the parenthesis are absolutes value of t-ratio next to the coefficient.

Table 5 Diagnostic Statistics

\begin{tabular}{|l|c|c|c|c|c|c|c|}
\hline \multicolumn{1}{|c|}{ INDUSTRIES } & F-Test & ECMt-1 & LM & RESET & CUSUM & CUSUMSQ & Adj. R2 \\
\hline Import & 7.25 & -0.43 & 1.58 & 0.78 & $\mathrm{~S}$ & $\mathrm{~S}$ & 0.89 \\
\hline $\begin{array}{l}\text { Agricultural and allied } \\
\text { products }\end{array}$ & 9.19 & -0.54 & 0.78 & 0.19 & $\mathrm{~S}$ & $\mathrm{US}$ & 0.80 \\
\hline Ores and minerals & 3.84 & -0.26 & 0.28 & 0.03 & $\mathrm{~S}$ & $\mathrm{~S}$ & 0.71 \\
\hline $\begin{array}{l}\text { Manufacturing (chemicals } \\
\text { and related products) }\end{array}$ & 19.40 & -0.55 & 0.10 & 0.89 & $\mathrm{~S}$ & $\mathrm{~S}$ & 0.73 \\
\hline $\begin{array}{l}\text { Manufacturing (engineering } \\
\text { goods) }\end{array}$ & 7.03 & -0.73 & 1.54 & 0.22 & $\mathrm{~S}$ & $\mathrm{~S}$ & 0.66 \\
\hline Textiles & 4.75 & -0.59 & 1.34 & 0.05 & $\mathrm{~S}$ & $\mathrm{US}$ & 0.72 \\
\hline Other manufactured goods & 8.30 & -0.39 & 0.34 & 0.05 & $\mathrm{~S}$ & $\mathrm{~S}$ & 0.90 \\
\hline
\end{tabular}

Notes: (a) Numbers inside the parentheses in the $\mathrm{ECM}_{\mathrm{t}-1}$ column is absolute t-ratio

(b) ${ }^{* * *}$ Indicates significance at $1 \%$ level, ${ }^{* *}$ indicates significance at $5 \%$ level, ${ }^{*}$ indicates significance at $10 \%$ level

(c) The critical value of F-test at $1 \%, 5 \%, 10 \%$ significance level when $\mathrm{k}=5$, is $4.15,3.38,3$.

(d) The LM is Lagrange Multiplier of residual correlation. It is distributed as $x^{2}$ with one degree of freedom and critical values at $1 \%, 5 \%, 10 \%$ level is 6.63, 3.84,2.71.

(e) The RESET is Ramsey test for functional misspecification is also distributed as $\mathrm{x}^{2}$ with one degree of freedom and critical values at $1 \%, 5 \%, 10 \%$ level is $6.63,3.84,2.71$.

coefficient, while the agricultural and allied sectors have a significantly negative estimated coefficient and the processing sector (chemical and associated products) has a significantly positive estimated coefficient.. The F-test stated in Table 5 is also important for the long-run forecasts, indicating that the variables are co-integrated in all industries. 
Thereafter, we observe the long-run effect of real exchange rate and India's income in the import demand model Table 4, the exchange rate in 2 industries is significant. Whilst, in 5 industries their coefficient are positive so, the estimate coefficient volatility discourage the aggregate import by -0.03 , which lays $100 \%$ increase in the volatility of exchange rate will lead to only $3 \%$ fall to overall import of India. On the industry-level the estimated co-efficient of volatility of agricultural \& allied and manufacturing (chemical related goods) industry discourage the import by -0.05 and -0.20 which further indicate that $100 \%$ increase in the volatility will attract $5 \%$ and $20 \%$ fall in each industry. As predicted, the relationship of price with the import demand model stands inversely. Thus it explains that price(lnPrice) in the manufacturing (chemical and related products) industry is -0.52 , showing large price elasticity in this industry imported to India. Therefore the results are consistent with the finding of Bahmani-oskooee \& Baek, (2016). Findings of Arize, (2000) on seven countries and (Yücel, Eren, $\&$ Ferya, 2019) on Turkey also lay discouraging effect of exchange rate volatility on trade.

As, the upper bound critical value of 2.08 is surpassed by the F-statistics assessed for the combined relevance of lagged level variables. For the remaining commodities, we use the long-run coefficient from eq. 1 to produce the ECM error-correction expression, and then we approximate the model by replacing the lagged-level vector with $\mathrm{ECM}_{\mathrm{t}-1}$ in Eq. 2. Next, if the ECMt-1coefficient is strongly negative, the co-integration into long-run equilibrium is supported. In both models, the ECMt-1 coefficient is high and strongly negative, indicating an average monthly correction, as seen in Table 5 .

Table 5 also provides the Lagrange Multiplier (LM), which is spread as $\chi^{2}$ by 1 degree of freedom and tests the residual correlation of each predicted error-correction model, which is hardly important, indicating auto-correlation free residuals. Ramsey's RESET test is mostly used to scan for model misspecification, which would also be distributed as $\chi^{2}$ with one degree of independence. It is significant in all industries (more than the critical value of 6.63). Also, we report the CUSUM as well as CUSUMSQ test presenting the stability of both long-run and short-run coefficient estimates and specification is found stable in most of the industries except agriculture \& allied and textile industry. The CUSUM and CUSUMSQ are labelled ' $S$ ' for stable model and 'US' for instable model in Table 5. Since the majority of the models mentioned are a good match, we also use modified $\mathrm{R}^{2}$ as a presenting indicator of goodness of fit.

\section{CUSUM and CUSUMQ Graphs}

Import

Figure 1

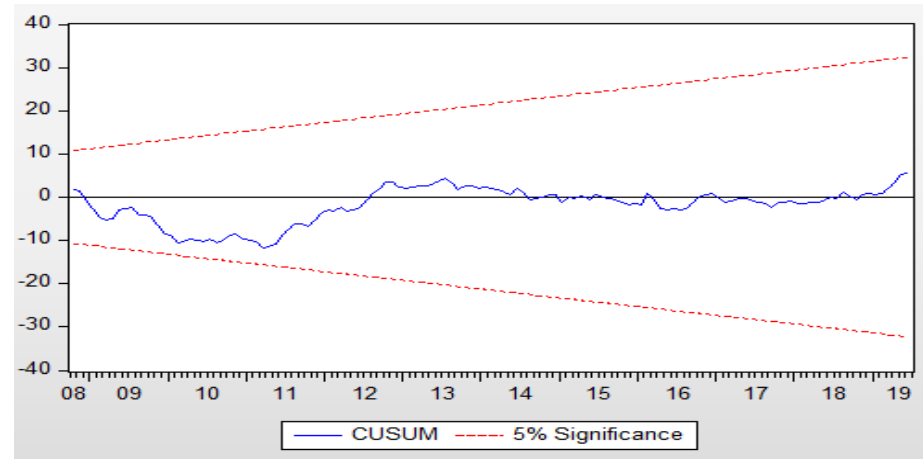


Figure 2.

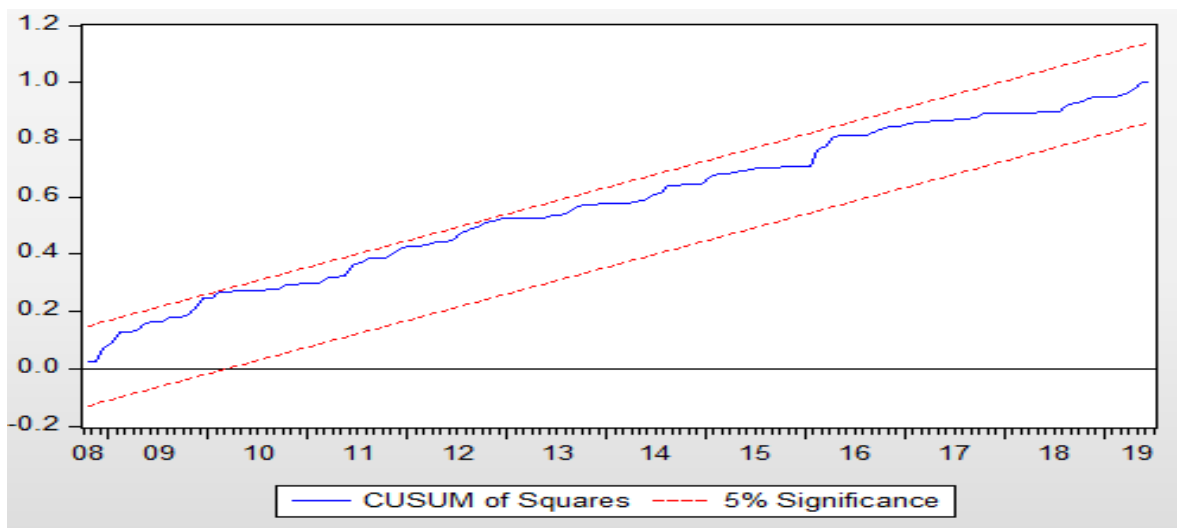

Industry-wise

(1) Agricultural and allied products

\section{Figure 3}

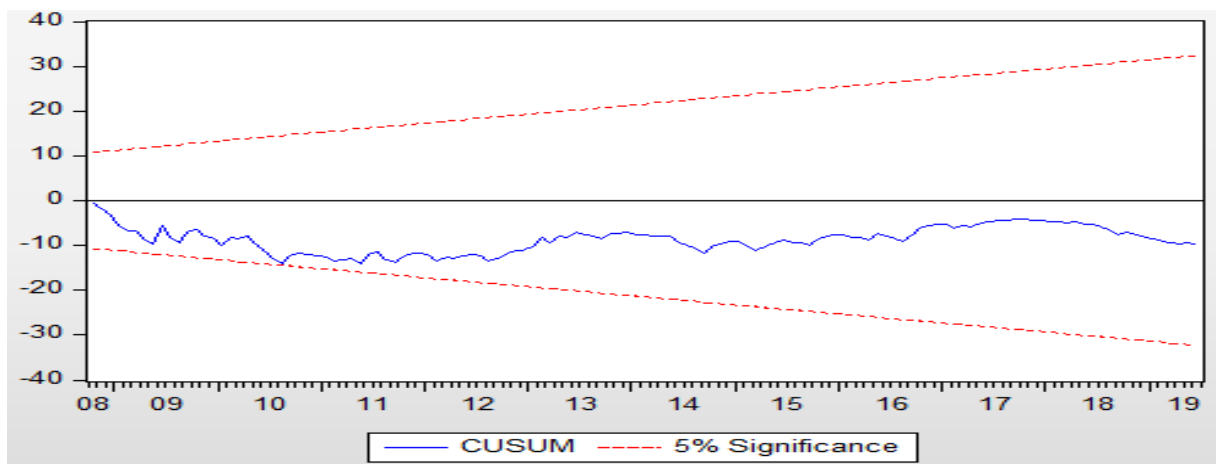

Figure 4

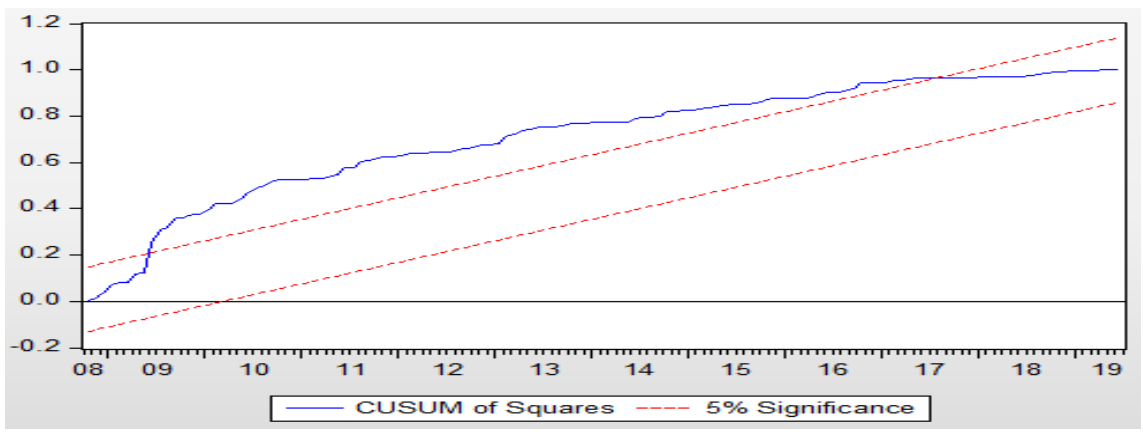

(b) ‘***'; '**' and ‘*' indicates significance level at 1\%; $5 \%$ and $10 \%$. 
(2) Ores \& Minerals

Figure 5

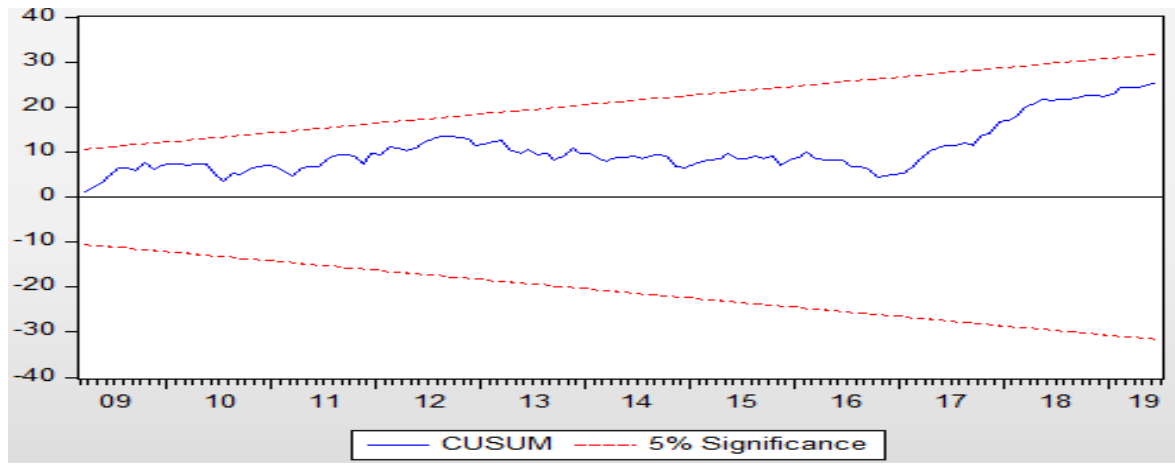

Figure 6

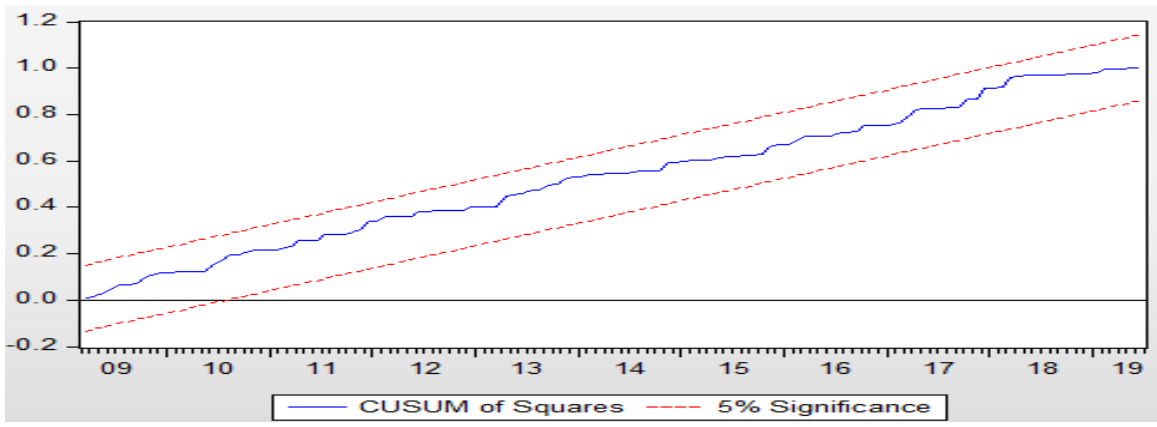

(2) Manufactured goods (chemical and related products)

\section{Figure 7}

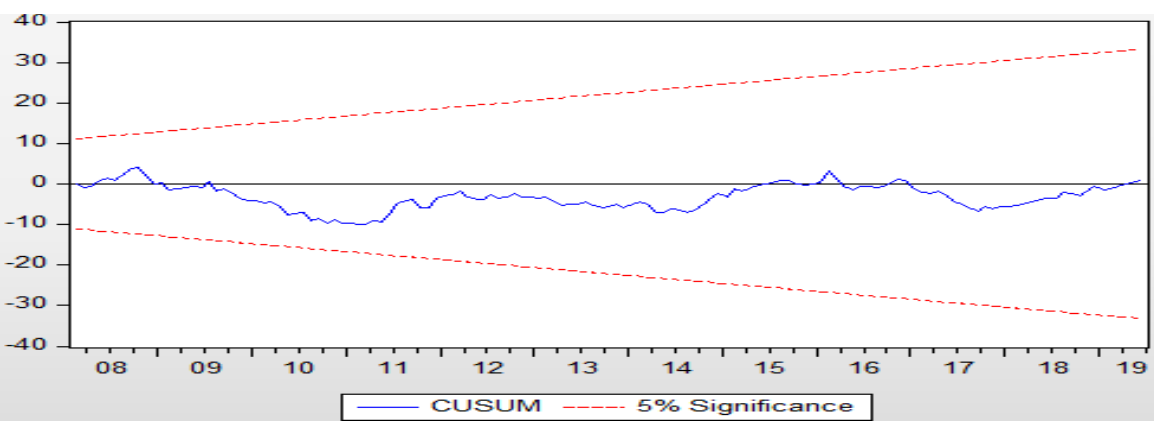




\section{Figure 8}

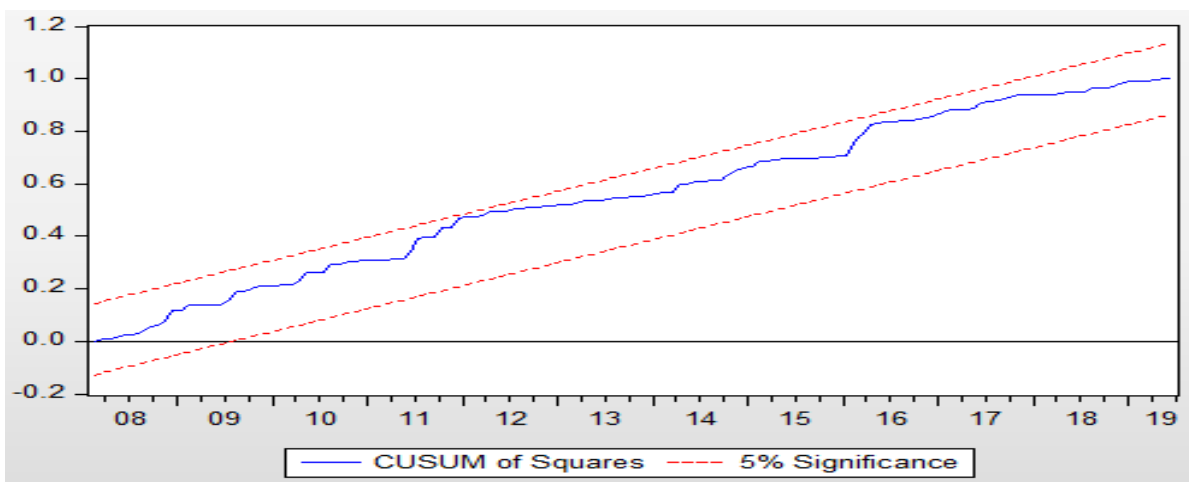

(4) Manufactured goods (engineering goods)

Figure 9

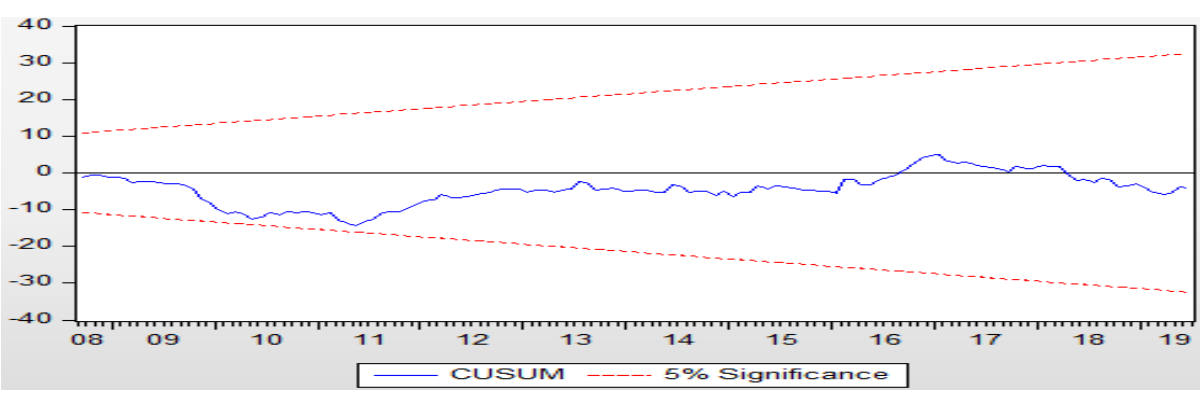

Figure 10

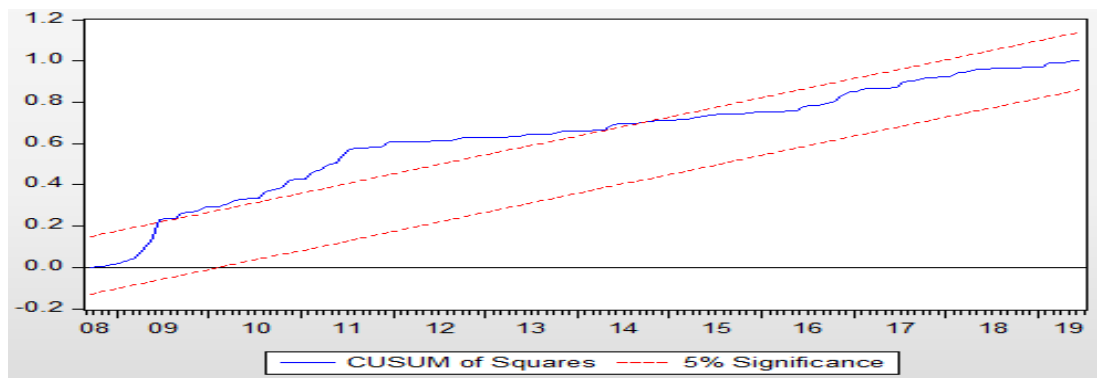

(5) Textiles 
Figure 11

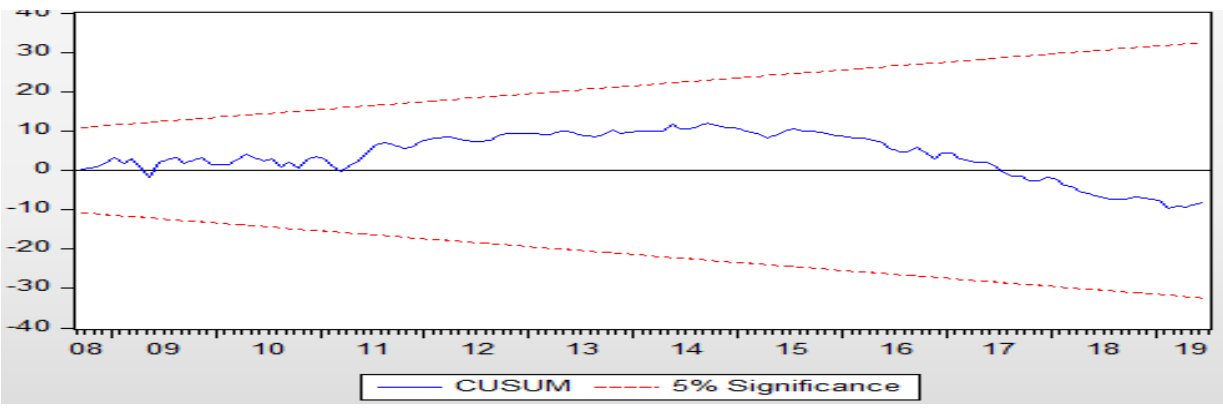

Figure 12

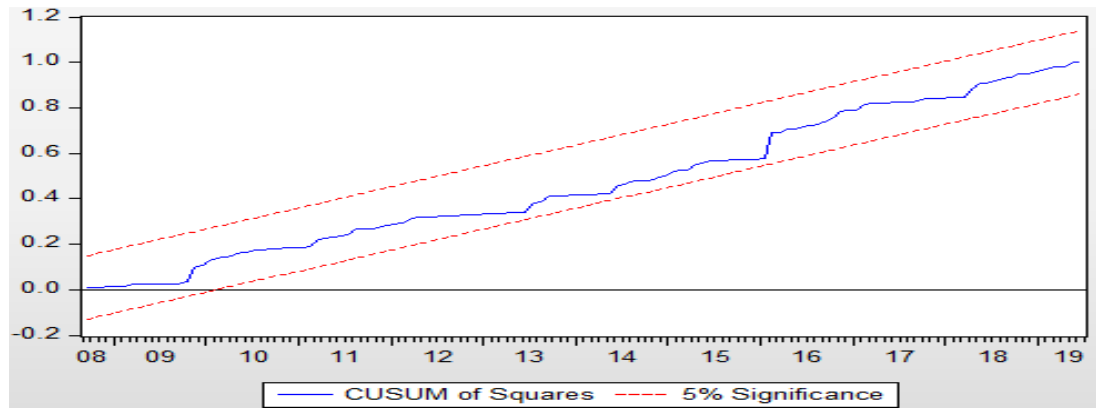

(6) Other manufactured goods

Figure 13

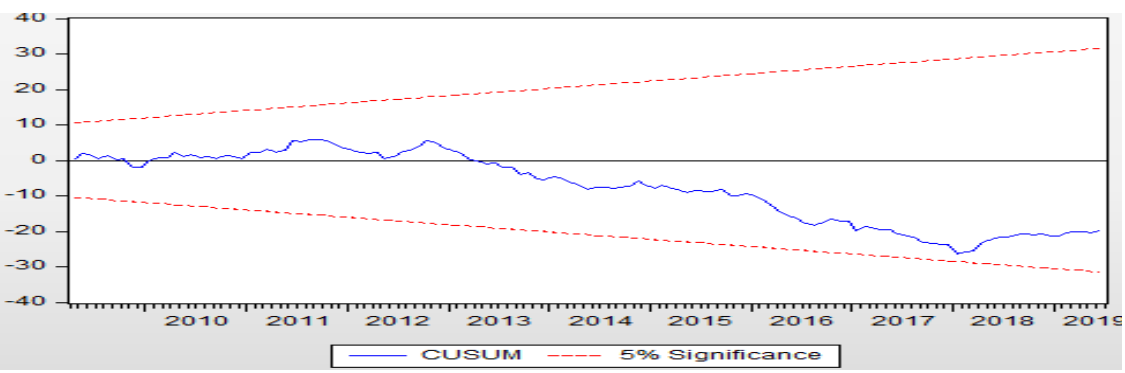




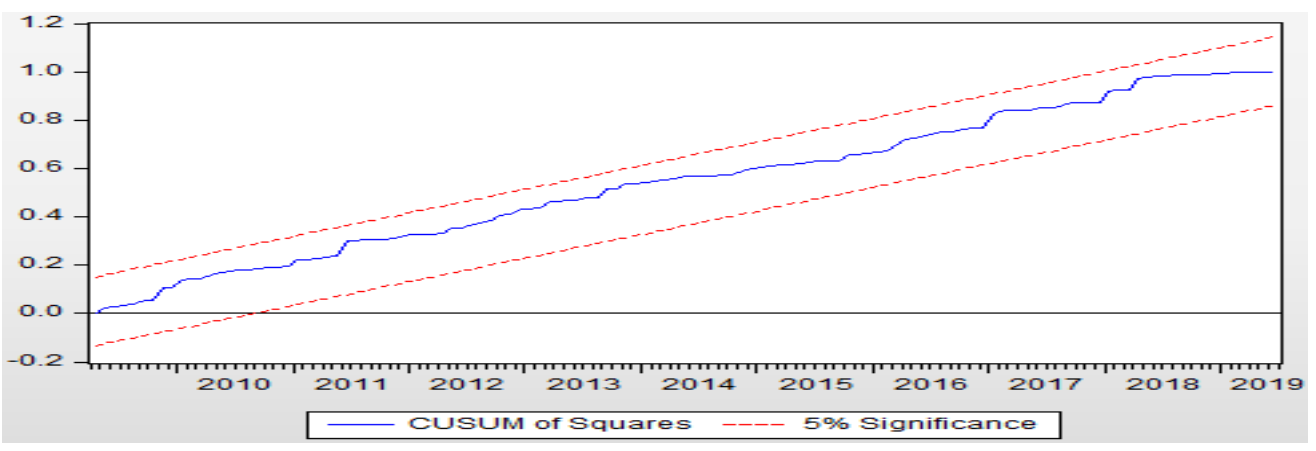

\section{CONCLUSION}

The study analyse the dynamic association between import industry of India, real exchange rate uncertainty. The analysis is on econometric model ARDL for predicting the short-run and longrun effect and E-GARCH model is used to estimate the exchange rate volatility is a measure of the variability of the real exchange rate; it has both positive and negative effects on trade. In developing countries like India the uncertainty is mainly impose by the inflation rate. The main concern is exchange rate volatility which can harm or boost the decision of traders. As many literature recites, there are possible chances of trade to increase in some cases or no influence at all. Following that, ample of studies have done for various country- pair at disaggregate i.e. at individual level of commodities to test the impact of exchange rate volatility empirically. Thereby this study contributes in the literature by examining bilateral trade between India-U.S. import trades for 6 industries namely agriculture $\&$ allied, ores \& minerals, manufacturing (chemical related), manufacturing (engineering goods), textile, other manufacturing.

This study show that exchange rate volatility in the both short run significantly discourage all the industries and in long run, it significantly discourage the agricultural \& allied industry but not the manufacturing industry (chemical related). Also at looking at the overall import if the volatility increases by $100 \%$ then import will decline by $3 \%$. Therefore the results indicate the exchange rate volatility expose India's import to U.S. greatly. Additionally half the industries are price elastic and also sensitive to income of India. Many literature have predicted that exchange rate uncertainty either negatively or positively affected trade but at aggregate level and not at individual level. Thusly the prime focus of the study is to predict the same at disaggregate level.

As India's import performance is concerned, the results showcase that, exchange rate volatility has both positive and negative effect on import performance with U.S. Also, the long-run cointegration association is present among import industries, destination country's income, exchange rate and exchange rate volatility is supported by error-correction term being statistically significant. The prior finding of the study could be summarized as, the exchange rate volatility impact the trade flow showing impact of shortrun of import commodities and these shortrun effects carried to longrun in 2 industries. This seems as exchange rate volatility is a significant player in most of the commodities. Finally, it is observed that the economic condition has been longrun causal influence for the trading between the two nations. The accelerating growth is necessary of import in India from U.S. as United States is second largest trading partner country and first largest export trading partner country of India. Hereby, growth in import will also attract growth in export by importing the goods that will give economic advancement in technology, domestic competition in the market, enhancing the productivity growth of the economy (for instance Sharma \& Mishra, 2015 and Sharma, 2016). Therefore, its necessary to prevent import from exchange rate uncertainty. 


\section{POLICY IMPLICATION}

The findings of this report look at the effects of the country's exchange rate and trade policies. As a result of the outcome, it is expected that by reducing risk and ensuring exchange rate stability, Indian trade can develop. Secondly, as manufacturing industry seems to be price elastic, the policy maker should target the domestic goods to be competitive at international level. Thirdly, the depreciation adjustment policy need to be taken int consideration to stabilise the domestic price.

\section{Disclosure Statement}

The author announced no potential conflict of interest to research, publication or authorship.

\section{Data Availability Statement}

Data sharing is not applicable to this article as no new data were created or analyzed in this study.

\section{NOTES}

1. The data span is constrained to the accessibility of data for the Import industry.

2. For details of normalization and related concept, see Bahmani-oskooee \& Tankui (2008).

3. As reported dummy variables coefficient is significant in only in manufactured industry (chemical related), also signifies that they were affected by the great depression period majorly. 


\section{REFERENCES}

Abbas Ali, D., Johari, F., \& Haji Alias, M. (2014). The Effect of Exchange Rate Movements on Trade Balance: A Chronological Theoretical Review. Economic Research International, 2014, 1-7. doi:10.1155/2014/893170

Ali, D. A., Johari, F., \& Alias, M. H. (2014). The Effect of Exchange Rate Movements on Trade Balance : A Chronological Theoretical Review. Academic Press.

Arbabian, S., Ghasemy, M., \& Seyedghaleeh, F. (2019). The Assessment of the Symmetric and Asymmetric Effects of Exchange Rate Volatility on the Flow of Iranian-Chinese Industrial Trade. Indian Economic Review, O(4), 999-1023. doi:10.22059/ier.2019.70035

Ariccia, G. D. (1999). Exchange rate fluctuation and trade flow evidence from the European union. Academic Press.

Arize, A. C. (2000). Conditional Exchange-Rate Volatility and the Volume of Foreign Trade : Evidence from Seven Industrialized Countries. Southern Economic Journal, 64(1), 235-254. doi:10.2307/1061049

Arize, A. C., Malindretos, J., \& Igwe, U. (2017). Do Exchange Rate Changes Improve the Trade Balance: An Asymmetric Nonlinear Cointegration Approach. International Review of Economics \& Finance, 49, 313-326. Advance online publication. doi:10.1016/j.iref.2017.02.007

Asteriou, D., Masatci, K., \& Keith, P. (2016). Exchange rate volatility and international trade : International evidence from the MINT countries. Economic Modelling, 58(November), 133-140. 10.1016/j.econmod.2016.05.006

Baharumshah, A. Z. (2001). The Effect of Exchange Rate on Bilateral Trade Balance : New Evidence from Malaysia and Thailand. Asian Economic Journal, (1973).

Bahmani-oskooee, M., \& Aftab, M. (2017). On the asymmetric e ff ects of exchange rate volatility on trade flows : New evidence from US-Malaysia trade at the industry level. Economic Modelling, 63, 86-103. doi:10.1016/j. econmod.2017.02.004

Bahmani-oskooee, M., \& Arize, A. C. (2019). On the Asymmetric Effects of Exchange Rate Volatility on Trade Flows : Evidence from Africa. Emerging Markets Finance \& Trade, 00(00), 1-27. doi:10.1080/154049 6X.2018.1543582

Bahmani-oskooee, M., \& Baek, J. (2016). Do Exchange Rate Changes have Symmetric or Asymmetric Effects on the Trade Balance? Evidence from U. S. -Korea Commodity Trade. Journal of Asian Economics, 45, 15-30. Advance online publication. doi:10.1016/j.asieco.2016.06.001

Bahmani-oskooee, M., \& Mitra, R. (2008). Exchange Rate Risk and Commodity Trade. Open Economies Review, 19(1), 71-80. doi:10.1007/s11079-007-9009-9

Bahmani-oskooee, M., \& Tankui, A. (2008). The black market exchange rate vs the official rate in testing PPP : Which rate fosters the adjustment process? 10.1016/j.econlet.2007.05.024

Choi, G. A. A. H. (2019). Dynamics of India's exchange rate and trade balance - The J curve hypothesis. Indian Journal of Economics and Business, 18(2), 457-466.

Clark, P. B. (1973). Uncertainty, exchange risk, and the level of international trade. Academic Press.

Çulha, O. Y., Eren, O., \& Öğünç, F. (2019). Import demand function for Turkey. Central Bank Review, 19(1), 9-19. doi:10.1016/j.cbrev.2019.03.001

Cushman, D. O. (1988). U.S. bilateral trade flows and exchange risk during the floating period. Academic Press.

Devereux, M. B., \& Lane, P. R. (2003). Understanding bilateral exchange rate volatility. Journal of International Economics, 60(1), 109-132. doi:10.1016/S0022-1996(02)00061-2

Dickey, D. A., \& Fuller, W. A. (1979). Distribution of the Estimators for Autoregressive Time Series with a Unit Root. Journal of the American Statistical Association, (March), 37-41.

Dogru, T., Isik, C., \& Sirakaya-Turk, E. (2019). The balance of trade and exchange rates: Theory and contemporary evidence from tourism. Tourism Management, 74(January), 12-23. doi:10.1016/j.tourman.2019.01.014 
Emran, M. S., \& Shilpi, F. (1996). Foreign exchange rationing and the aggregate import demand function. Economics Letters, 51(3), 315-322. doi:10.1016/0165-1765(96)00824-5

Giovannini, A. (1988). Exchange rates and traded goods prices. Journal of International Economics, 24.

Glosten, L. R., Jagannathan, R., \& Runkle, D. E. (1993). On the Relation between the Expected Value and the Volatility of the Nominal Excess Return on Stocks. The Journal of Finance, XLVIII(5), 1779-1801. doi:10.1111/j.1540-6261.1993.tb05128.x

Goldar, B. (2002). Trade liberalization and manufacturing employment : The case of India. Https://Www.Ilo. Org/Wcmsp5/Groups/Public/---Ed_emp/Documents/Publication/Wcms_142365.Pdf

Grauwe, P. D. E. (1988). Exchange Rate Variability in Growth and the Slowdown Trade of International. Academic Press.

Jerry, G., \& Thursby, M. C. T. (1987). Bilateral trade flows, the Linder hypothesis, and exchange risk. Academic Press.

Jiménez-rodríguez, R., \& Morales-zumaquero, A. (2019). Nominal and Real Exchange Rate Co-Movements. $10.1016 / \mathrm{S} 1514-0326(14) 60013-1$

Kang, J. W., \& Dagli, S. (2018). International trade and exchange rates. Journal of Applied Econometrics, 21(1), 84-105. doi:10.1080/15140326.2018.1526878

Kharroubi, E. (2011). The trade balance and the real exchange rate. Academic Press.

Klaassen, F. (2004). Why is it so difficult to find an effect of exchange rate risk on trade? Journal of International Money and Finance, 23(5), 817-839. doi:10.1016/j.jimonfin.2004.03.009

Maurice Obstfeld, K. R. (1998). Risk and Exchange rates. Academic Press.

Mitra, A., Sharma, C., \& Ve, M. (2014). Journal of Asian Economics Trade liberalization, technology transfer, and firms ' productive performance : The case of Indian manufacturing. Journal of Asian Economics, 33, 1-15. doi:10.1016/j.asieco.2014.04.001

Nelson, D. B. (1991). Conditional Heteroskedasticity in Asset Returns : A New Approach. Society and Economy, 59(2), 347-370.

Peel, A. A. (1991). The effects of exchange rate volatility on exports. Economics Letters, 37(2), $173-177$. doi:10.1016/0165-1765(91)90127-7

Pesaran, M., Hashem, Y., \& Shin, R. J. S. (2001). Bounds testing approaches to the analysis of level relationships. Journal of Applied Econometrics, 289-326. 10.1002/jae.616

Peter Hooper, S. W. K. (1978). The effect of exchange rate uncertainity on the prices and volume of international trade. Academic Press.

Rajković, M., Bjelić, P., Jaćimović, D., \& Verbič, M. (2020). The impact of the exchange rate on the foreign trade imbalance during the economic crisis in the new EU member states and the Western Balkan countries. Economic Research-Ekonomska Istrazivanja, 33(1), 182-203. doi:10.1080/1331677X.2019.1708771

Rose, A. K. (1990). Exchange rates and the trade balance Some evidence from developing. Economics Letters, 34(3), 271-275. doi:10.1016/0165-1765(90)90130-S

Sharma, C. (2016). Does importing more inputs raise productivity and exports? Some evidence from Indian manufacturing. Economic Issues, 21, 1-21. doi:10.2139/ssrn.3184466

Sharma, C., \& Mishra, R. K. (2015). International trade and performance of firms: Unraveling export, import and productivity puzzle. The Quarterly Review of Economics and Finance, 57, 1-14. doi:10.1016/j.qref.2015.02.001

Sharma, C., \& Pal, D. (2018). Exchange rate volatility and India's cross-border trade : A pooled mean group and nonlinear cointegration approach. Economic Modelling, 74(April), 1-17. doi:10.1016/j.econmod.2018.05.016

Sharma, C., \& Pal, D. (2019). Does Exchange Rate Volatility Dampen Imports? Commodity-Level Evidence From India. International Economic Journal, 33(4), 696-718. doi:10.1080/10168737.2019.1630467 
Singh, T. (2002). India's trade balance : the role of income and exchange rates. Academic Press.

Tandon, S. (2014). Trade Balance and the Real Exchange Rate. Foreign Trade Review, 49(2), 117-139. doi: $10.1177 / 0015732514525222$

Topalova, P., \& Khandelwal, A. (2011). Trade liberalization and firm productivity: The case of india. The Review of Economics and Statistics, 93(August), 995-1009. doi:10.1162/REST_a_00095

Varangis, Y. Q. A. P. (1994). Does Exchange Rate Volatility Hinder Export Growth? Empirical Economics, 371-396.

Yücel, O., Eren, O., \& Ferya, O. (2019). Central Bank Review Import demand function for Turkey. Central Bank Review, 19(1), 9-19. doi:10.1016/j.cbrev.2019.03.001

Zakoian, J.-M. (1994). Threshold heteroskedastic models. Journal of Economic Dynamics \& Control, 18(5), 931-955. doi:10.1016/0165-1889(94)90039-6 


\section{APPENDIX A.}

\section{Data Sources and Definition}

Monthly data consisting the period of 2002:M09 to 2019:M06 are used for the empirical investigation.

\section{Database:}

1. The industry-wise data of bilateral trade between India and U.S. is extracted from the Economic outlook a database of Centre for Monitoring Indian Economy (CMIE).

2. The aggregate monthly import price index for India: International Financial Statistics (IFS) database of IMF.

3. Nominal exchange rate: International Financial Statistics (IFS) database of IMF.

4. National income for India is proxied by aggregate industrial production index (IIP) as GDP is extracted from the Reserve Bank of India.

5. The consumer price index (CPI) for India: International Financial Statistics (IFS) database of IMF.

\section{Variable Definition}

$\mathrm{M}_{\mathrm{i}}^{\mathrm{IND}}=\mathrm{It}$ is volume of industry $i$ imported to India. The import data is in dollars for each industry. As the price level of each industry is absent thereby the aggregate import price index is used as the second best deflator.

$\mathrm{Y}^{\mathrm{IND}}=$ It represent the India's income, measured by using proxy of aggregate industrial production index (IIP).

$\mathrm{RER}=\mathrm{It}$ is a bilateral real exchange rate between Indian Rupee and dollar: defined as $\left(\mathrm{P}_{\mathrm{IND}}\right.$ *NER/ $\mathrm{P}_{\mathrm{US}}$ ). NER is nominal exchange rate; $\mathrm{P}_{\mathrm{IND}}$ is $\mathrm{CPI}$-price level in India; $\mathrm{P}_{\mathrm{US}}$ is CPI- price level in United States.

$\mathrm{VOL}=$ It represent the measure of USD-IND real exchange rate.

For descriptive statistics see Table 6. 
Table 6 Descriptive Statistics

\begin{tabular}{|l|c|c|c|c|c|c|c|}
\hline Variable & Mean & Maximum & Minimum & St. deviation & Skewness & Kurtosis & Jarque-Bera \\
\hline RER & 3.9259 & 4.5279 & 3.4688 & 0.3051 & 0.3926 & 1.9383 & 12.49794 \\
\hline IIP IND & 4.5830 & 4.9891 & 4.0865 & 0.2320 & -0.5046 & 2.0932 & 13.19111 \\
\hline Price & 4.6147 & 4.7156 & 4.4587 & 0.0521 & -0.8550 & 3.5371 & 23.02095 \\
\hline Import & 10.0780 & 10.5435 & 9.3260 & 0.2657 & -0.2904 & 2.3735 & 5.229546 \\
\hline $\begin{array}{l}\text { Agricultural \& allied } \\
\text { Industry }\end{array}$ & 7.5577 & 8.8251 & 6.6539 & 0.5277 & 0.0456 & 1.9400 & 8.111416 \\
\hline $\begin{array}{l}\text { Ores \& minerals } \\
\text { Industry }\end{array}$ & 4.6179 & 6.1936 & 0.0000 & 1.2071 & -0.8224 & 3.0473 & 19.40337 \\
\hline $\begin{array}{l}\text { Manufactured } \\
\text { Industry (chemical } \\
\text { related) }\end{array}$ & 9.9031 & 10.3759 & 9.2049 & 0.2562 & -0.0606 & 2.4069 & 2.626259 \\
\hline $\begin{array}{l}\text { Manufactured } \\
\text { Industry (engineering } \\
\text { goods) }\end{array}$ & 8.4271 & 9.4464 & 0.3327 & 0.1836 & 0.1836 & 2.8401 & 1.149553 \\
\hline Textiles Industry & 7.5330 & 8.0375 & 6.7341 & 0.3001 & -0.3608 & 2.2622 & 7.633345 \\
\hline $\begin{array}{l}\text { Other manufactured } \\
\text { Industry }\end{array}$ & 8.7726 & 9.5698 & 7.8183 & 0.3058 & -0.1818 & 3.0894 & 1.004916 \\
\hline
\end{tabular}

Notes: Observations 202

Mohini Gupta is working diligently as a Doctoral Fellow in the Department of HSS at Jaypee Institute of Information Technology (JIIT) Noida (U.P), India. She has completed her graduation from Delhi University and Master's from the Amity University. She has decorously presented academic papers at national and international conferences. Her specific area of research typically includes macroeconomics, International Economics, Energy Economics. She publishes extensively in national and international journals in the key areas of economics.

Sakshi Varshney is working as an Assistant Professor (Senior Grade) in the Department of Humanities and Social Sciences in Jaypee Institute Information Technology (JIIT) Noida, UP, India. She has more than 11.5 academic years of valuable experience in teaching and research. She has completed her Master's and PhD in Finance from the University of Lucknow, India. She produces many publications in national and international journals. Her key area of research typically includes microeconomics, macroeconomics, finance, global finance public finance. 